\title{
The Impact of Source And Use of Funds on Liquidity at PT. Mustika Ratu Tbk.
}

\author{
Rudi Sanjaya1)
}

1) Dosen Universitas Pamulang, e-mail : rudisanjaya938@gmail.com

\section{ARTICLES INFORMATION}

ABSTRACT

\section{JURNAL SEKURITAS \\ (Saham, Ekonomi, Keuangan dan Investasi ) \\ Vol.3, No.2, Januari 2020 Halaman : $158-165$ \\ (C) LPPM \& Prodi Manajemen UNVERSITAS PAMULANG}

\section{ISSN (online) : 2581-2777 \\ ISSN (print) : : 2581-2696}

\section{Keyword :}

Liquidity; source of funds; Use of funds

JEL. classification :

C33, G21, G24, N15, N25

\section{Contact Author :}

PRODI MANAJEMEN UNPAM

JL.Surya Kencana No.1

Pamulang Tangerang Selatan Banten

Telp. (021) 7412566, Fax (021) 7412491 Email :

sekuritas@unpam.ac.id
The purpose of this research is to know the source and use of funds at PT. Mustika Ratu, to find out Liquidity of PT. Mustika Ratu Tbk and to know the influence of sources and the use of funds to liquidity at PT. Mustika Ratu Tbk.

Research methods used is a quantitative descriptive that is doing discussion of the problems faced to the company's performance of financial aspects. the analytical data used are data that is data are numeric. Samples used in this study i.e. balance sheet, Profit and loss report on PT. Mustika Ratu Tbk Year 2010 to with 2013. The qualitative data i.e. data not stated in the form of numbers, like a brief history of PT. Mustika Ratu Tbk and business field of PT. Mustika Ratu Tbk. Determining whether a relationship is between the source and the use of funds at PT. Mustika Ratu Tbk with liquidity used method of regression equation analysis, coefficient of determination and test of significance.

Result of source influence and use of funds with liquidity the presence of strong relationships and between the source and the use of funds and liquidity means having a relationship has a direct relationship. The magnitude of the source relationship the use of funds with liquidity $92.16 \%$ which means that the source and the use of funds affects the Sufficient liquidity. While the rest which is $7.84 \%$ influenced by factors other causes. In this case the source and use of funds (92.16\%) describe that PT. Mustika Ratu Tbk has a fairly good relationship in the improve the company's financial performance. Other factors (7.84\%). Based on test hypothesis, it is known that based on results calculation of the research $\mathrm{T}$ count Smaller than $\mathrm{t}$ table $3.42<$ 6.31 then $\mathrm{Ho}$ accepted and $\mathrm{Ha}$ is rejected meaning that hypotheses the source and use of funds not have a convincing relationship (not significant) with liquidity. 


\section{A. INTRODUCTION}

Rapid development Economy today influence the development of the business. Among them are man:' prohlems faced by various types of companies, including management of funds efficiently to support the company's activities. Companies must be able to use available funds and to implement it to realize company objectives. Sufficient funds much needed for activities in efforts to capitalize on the opportunities and to face threats arising from competitors and caused by the occurrence of difficulties financial.

Proper management of funds play an important role to ensure the smoothness and stability company operations. Besides managers who are in the company need to the development that occurred in the in other economic sectors, such as interest rate on the banking may affect changes that concern the issue of source of funds.

Basically financial statements is the final result From a process of recording summarize all transactions that are of a nature financials during the financial year or period the accounting concerned and usually presented in the form of a balance sheet, income statement, change report capital or retained earnings statement.

Besides the financial statements there are still major reports other finances are also very important for a company to find out the company's performance in terms of efficiency of funds i.e. to the extent which the company is able to manage and spend these funds, report this is what is called a report source and use of funds.

Source and usage reports funds intended to provide information to management about the company's current financial position, whether bigger or smaller source and use. Other than that, can also be known from where the source company funds during the period and where the funds are spent and invested, whether its allocation have gone on effective and efficient in accordance with the objectives planned.

The funds are too large allow for Idlefund. In order to be able to judge a company's financial position in completing its obligations, then an analysis tool needs to be used called liquidity ratio, meaning ratio which shows ability company in paying obligations the short term (Riyanto, 2001: 25). Low liquidity can cause the company to experience losses, including not being fulfilled obligations to creditors. From This ratio calculation is expected to be able help managers to judge effectiveness and efficiency of funds which company used in run his business.

Based on the description that has been stated, the authors are interested in conduct research in preparation thesis with the title: "Influence Source and Use of Funds Against Liquidity at PT. Mustika Ratu Tbk". Based on the background of the problem and limitation of problems raised above, some can be formulated problems namely: (1) How to source and use funding to PT. Mustika Ratu Tbk?, (2) How about liquidity at PT. Mustika Ratu Tbk?, (3) How does the source and influence use of funds against liquidity at PT. Mustika Ratu Tbk?. The objectives of this research are: (1) To know the source and use of funds at PT. Mustika Ratu, (2) To find out Liquidity of PT. Mustika Tbk, and (3) To know the influence of sources and the use of funds to liquidity at PT. Mustika Ratu Tbk.

\section{B. LITERATURE REVIEW}

\section{Financial Statements}

Definition of financial statements according to Sofyan Syafri Harahap (2010: 11) is a media information that summarizes all activities company. If this information presented correctly, the information it is very useful for anyone to make decisions about companies reported.

Raharjo (2009:1) suggested that "the report Finance is a report of the responsibility answer manager or leader management of the company that is entrusted to the 
Stakeholders or parties of interest outside the company: Company owners, Governments, Creditors and other parties ".

2. Funding source

According to Riyanto (2004:25) Sources of funds Company will be realized in Various financial assets for example Stock, bonds, bank account balances and others. By Lukman Dendawijaya (2009:46) source of bank funds is a bank fund that is used as a tool for the operations of a bank.

With the decision to conduct investment, funds are required to budget investments, arise problems how companies can obtain the funds needed to Planned investments on the conditions most considering that the owners of the Fund are for the use of its funds and is a the planned investment costs. Summed up company funds will be realized in various financial assets for example, stocks, bonds, bank account balances etc.

3. Use of funds

By Riyanto (2004:95) states that the use of funds will cause changes in form and decrease in the amount of assets smoothly, but decrease in assets not always followed by a decrease in funds.

4. Financial Ratios Analysis

Definition of financial Ratio analysis according to Harahab (2010:297) is the number derived from the comparison of one post financial statement with the post other relationship with the rlevant and significant. This financial ratio only simplifies information describing the relationship between a particular post and other posts, with this simplifications we can quickly assess the relationship between post and can compare with other ratios so that it can gain information and provide assessments.

Financial Ratio analysis can help us know the performance the company either in whole or in detail from time to the time, including its human resources. For example analysis of sales, costs and expenses, procurement of goods, distribution, and field of including evaluating and measuring productivity or performance of its leaders and employees

5. Liquidity

Understanding Liquidity According to Husnan and Pudjiastuti (2004:14) namely: "Liquidity is a company's ability to meet obligations that must be met soon". Riyanto (2001:25) states that: "Liquidity is the ability company to fulfill financial obligations to be immediately fulfilled ".

Not only short-term banks and lenders are very attentive to this liquidity ratio, but it is also important for long-term creditors and shareholders who eventually want to the prospects of the dividend and interest payment in the future will come. Liquidity is used as a financial reporting analysis tool to know the company's short-term financial capabilities. One of the main concerns of most analyses the uniqueness is liquidity. Liquidity relates to obligations that must be fulfilled immediately. The financial obligations of a company essentially consist of financial obligations relating to outside parties (debtors) and financial obligations related to the production process (internal company).

\section{RESEARCH METHODOLOGY}

The population used in the study was financial statement of PT. Mustika Ratu TBK. Samples in the this research is the financial report of the period 2010-2013 PT. Mustika Ratu TBK . Secondary data are obtained in the form of the annual report and financial statements in the form balance sheet and income statement of PT. Mustika Ratu Tbk. and qualitative data i.e. data not stated in numeric forms, such as a short history company and company line of business. Methods used in of data collection with respect to these are: (1) Documentation, data collection and information obtained from the documents Company, (2) Literature study, collection of data obtained from the library, such as articles, books, financial and internet reports.

Operational definitions of variables in this study the authors set 2 (two) variables which used by : Independent Variable (free), i.e. variable that is the cause occurrence or influence dependent variable. As a variable free in this research is source and use of funds. 
Dependent variable (bound), i.e. variables that are affected by independent variable. As a variable bound in this research is liquidity. The data determination techniques in this study use primary data and secondary data in accordance with the data researchers need.

This research uses the method of data analysis panel because of the data used through the process of merging between time series data with the data between individuals (cross section) called the data panel. In this research the author uses the help of the program EViews 8.0 to analyze the data obtained, namely managing the influence of sources and the use of funds to the liquidity of PT. Mustika Ratu, Tbk. After managed data Results obtained.

\section{RESULTS AND DISCUSSION}

Influence of source and use Funds against liquidity at PT Mustika Ratu, Tbk. Calculation the influence of sources and the use of funds to liquidity at PT. Mustika Ratu, Tbk authors will analyze Statistics. To declare a relationship Statistically functional authors classify the source and use of funds as a variable free (Independent Variable) and liquidity level identified as variable binding (Variable dependent). For calculations will use the formula:

a. Simple regression analysis

$Y=a+b X$

In such regression, researchers sought coefficient of $a$ and $b$ coefficient, value $A$ and $b$ searched by using the formula as following:

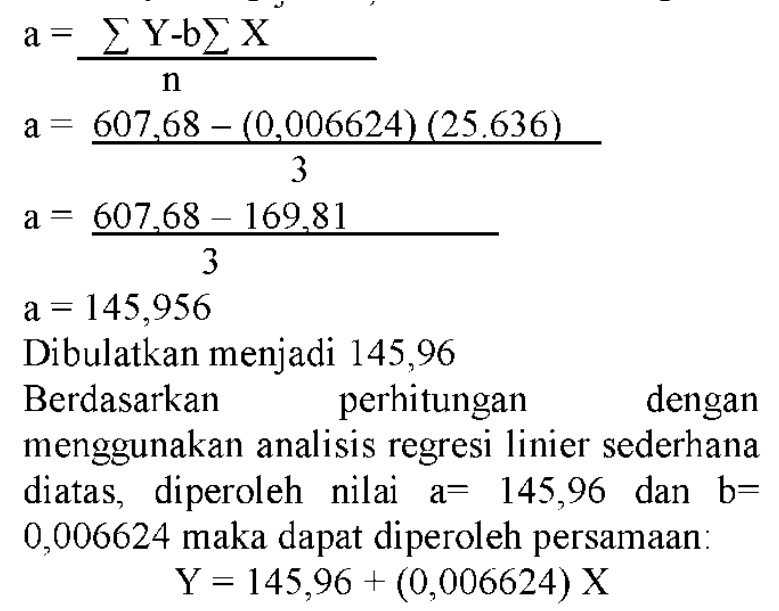

To specify the value $b$ can be used formula as follows:

$$
\begin{aligned}
& \mathrm{b}=\frac{\mathrm{n}\left(\sum X Y\right)-\left(\sum X\right)\left(\sum Y\right)}{\mathrm{n}\left(\sum X^{2}-\left(\sum X\right)^{2}\right.} \\
& \mathrm{b}=\frac{3(5.311 .958,13)-(25.636)(607,68)}{3(332.937 .206)-(25.636)^{2}} \\
& \mathrm{~b}=\frac{17.973 .959,04-15.578 .484,48}{998.811 .618-657.204 .496} \\
& \mathrm{~b}=\frac{2.395 .474 .56}{361.607 .122} \\
& \mathrm{~b}=0,006624522
\end{aligned}
$$

Dibulatkan menjadi 0,006624

b. Korelasi Product Moment Korelasi sebagai berikut:

$\mathbf{r} \quad \mathbf{n} \cdot \sum \mathbf{X Y}-\sum \mathbf{X} \cdot \sum \mathbf{Y}$




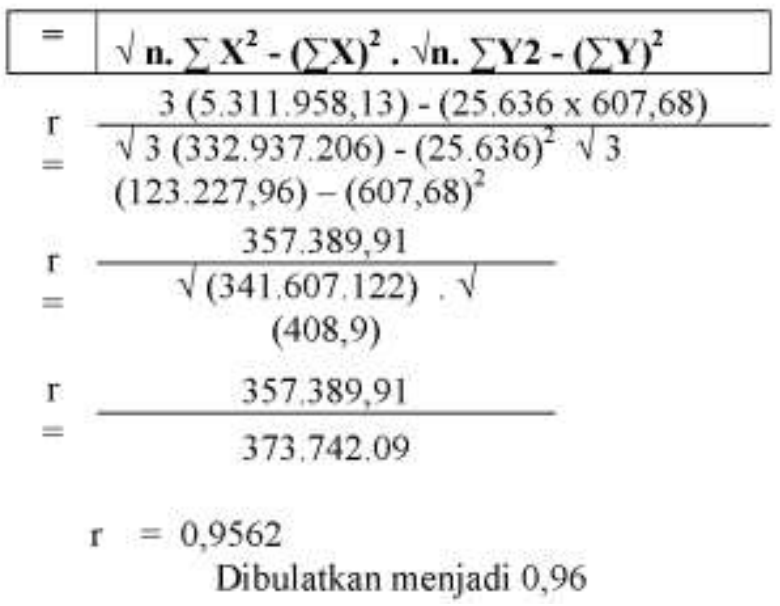

c. Coefficient of Determination

While to find out how the magnitude of the influence of sources and uses funds in influencing liquidity can measured by the coefficient of determination or the determining coefficient as follows:

$$
\begin{aligned}
\mathrm{Kd} & =\mathrm{r} 2 \times 100 \% \\
\mathrm{Kd} & =0.962 \times 100 \% \\
& =0.9216 \times 100 \% \\
& =92.16 \%
\end{aligned}
$$

With the results obtained calculation of the coefficient of determination then it can be concluded that the increase liquidity is caused by sources and the use of funds is $92.16 \%$ whereas the remaining $7.84 \%$ is influenced by other factors.

d. Hypothesis testing

Calculation of Sample Statistics

$$
\begin{aligned}
\text { thitung } & =\frac{r \sqrt{n-2}}{\sqrt{1+r^{2}}} \\
= & \frac{r \sqrt{3-2}}{\sqrt{1-0,96^{2}}} \\
= & \frac{0,96 \sqrt{3}-2}{\sqrt{1-(0,9216)}} \\
& =\frac{0,96 \sqrt{1}}{\sqrt{1-(0,9216)}} \\
& =\frac{0,96}{\sqrt{0,07}} \\
& =3,42
\end{aligned}
$$

Tingkat sgnifikan

$\alpha=$ taraf nyata $5 \%$

$\mathrm{t} \alpha=(\mathrm{df}=\mathrm{n}-2)$

$\mathrm{t}=(0,05=3-2)$

$\mathrm{t}=(0,05: 1)$

$\mathrm{t}=6,31$ 
Based on calculations where tCount $=3.42$ for error rate of $5 \%$ and ttable $=6.31$ So it can be known that tCount $<$ ttable or $3.42<6.31$. With Ho accepted means there is no significant relationship between the source and the use of funds to liquidity at PT. Mustika Ratu, Tbk Indonesia.

\section{E. CONCLUSIONS}

After analysis of the PT. Mustika Ratu, Tbk author take the following conclusions:

1. Source and use of funds at PT. Mustika Ratu, Tbk year 2011 to 2013 experiencing Significant changes in company funds. In 2011 up to 2013 total funds the decline, it is in accordance with the source policy and the use of outgoing funds company to increase revenue company through payment funding, financing, and investment. Value in year 2011 up to the year 2013 is total resources and use of funds year $2011=R p 17,258,242$, year $2012=$ Rp 4,149,592, year $2013=$ Rp 4,229,853 Attempts company in particular part marketing in the lease space to tenants or counters such as rental value to a tenant the existing business and efficiency efforts costs for each department expenses such as technical costs, parking fees, and cost promotion.

2. Liquidity at PT. Mustiak Ratu, Tbk in 2011 until the year 2013 , tend to be stable and able categorized as safe from problems. This situation can be seen from the level stable liquidity around $211.69 \%$ up to $195.62 \%$.

3. There is no influence and significantly influence of source and use funds against liquidity at PT Mustika Ratu, Tbk has the closeness of the relationship is 0.96 or can be categorized that relationship so strong and unidirectional. Relationship positively addressed that the relationship between source and use of funds to direct liquidity, meaning that when the source and use of funds increased, the level of increased liquidity otherwise when the source of and use of funds experienced the liquidity is experiencing the decline. whereas based on calculation of coefficient of determination resources and use of funds affect the liquidity of $92.16 \%$, which means the source and the use of funds gives very strong influence in the assess the liquidity level of PT Mustika Ratu, Tbk and the remaining $7.84 \%$ influenced by other factors. Where test $t$ show the count of $<\mathrm{t}$ table or $3.42<6.31$ and regression calculations it can be concluded that a value or a constant of 145.36 meaning, if any resources and usage improvements the liquidity of 145.36 and the $b$ value of 0.006624 , because value of positive value, then indicates a relationship that comparable (significant) equals the rise of sources and 1 Rupiah use of funds liquidity will be subjected to a hike of 0.006624 at PT Mustika Ratu, Tbk. 


\section{REFERENCES}

Abdul Kadim, K., \& Nardi Sunardi, S. (2018). Determinant Of Company's Likuidity And It's Implications On Financial's Performance Of Ritail Trade Company's In Indonesia At The Period Of 2008-2017. Global and Stockhastic Analysis, 5(7), 235-247.

Abdul Kadim, K., \& Nardi, S. (2018). Eviews Analysis: Determinant Of Leverage And Company's Performance. Global and Stochastic Analysis (GSA), 5(7), 249-260.

Dendawijaya, Lukman. 2009. "Manajemen Perbankan". Edisi Kedua. Jakarta: Ghalia Indonesia.

Harahap sofyan Safri. 2010. "Analisis Kritis Atas Laporan Keuangan". Jakarta: PT. Raja Grafindo Persada.

Husnan, Suad dan Pudjiastusti, Eny. 2002. "Dasar-Dasar Manajemen Keuangan". Edisi Ketiga. Yogyakata: Akademi Manajemen Perusahaan YKPN.

Kadim, A., \& Sunardi, N. (2019, May). Eviews Analysis; Determinan Tourism, Restaurant and Hotel Company's Soundness and Performance. In Proceeding Interuniversity Forum for Strengthening Academic Competency (Vol. 1, No. 1, pp. 332-340).

Kasmir. 2008. "Analisis Laporan Keuangan". Jakarta: PT. Rajawali.

Kasmir. 2014. "Bank dan Lembaga Keuangan Lainnya". Cetakan Keempat Belas. Jakarta: PT. Raja Grafindo Persada.

Latumaerisa, Julius R. 2013. "Bank dan Lembaga Keuangan Lainnya". Jakarta: Salemba Empat.

Moh. Nazir. 2005. "Metode Penelitian". Jakarta: Ghalia Indonesia.

Munawir. 2007. “Analisa Laporan Keuangan”. Edisi 4. Yogyakarta: Liberty.

Raharjo, Budi. 2009. "Dasar-Dasar Analisis Fundamental Saham Laporan Keuangan Perusahaan Membaca, Memahami, dan Menganalisis". Yogyakarta: Gajah Mada University Press.

Riyadi selamet. "Banking Assets and Liability Management". Edisi Ketiga, Jakarta: Lembaga Penerbit Fakultas Ekonomi Universitas Indonesia, 2006.

Riyanto, Bambang. "Dasar-Dasar Pembelanjaan Perusahaan". Edisi Keempat. Yogyakarta: BPFC.

S. Munawir. 2002. "Analisa Laporan Keuangan". Cetakan Ketiga. Jakarta: PT Raja Grafindo Persada.

Sunardi, N. (2019). Profitabilitas, Likuiditas, Dan Multiplier Equity Pengaruhnya Terhadap Harga Serta Return Saham Pada Industri Manufaktur Tahun 20122017. INOVASI, 6(1), 58-73. 
Sunardi, N. (2019). Relevansi Intelectual Capital terhadap Harga dan Retun Saham di Industri Perbankan Pemerintah di Indonesia. JIMF (Jurnal IImiah Manajemen Forkamma), 3(1).

Sunardi, N., \& Sasmita, A. S. (2019). Pengaruh Likuiditas, Leverage Dan Growth Terhadap Kinerja Industri Makanan Dan Minuman Yang Tercatat Di Indonesia Stock Exchange Selama Periode Tahun 2011-2015. Jurnal Sekuritas (Saham, Ekonomi, Keuangan dan Investasi), 2(2), 81-97.

Sampurnaningsih, S. R. (2018). Analisis Makroekonomi Yang Mempengaruhi Likuiditas Pasar Dan Harga Saham Index Consumer Goods Bursa Efek Indonesia Selama Tahun 2017. Jurnal SEKURITAS (Saham, Ekonomi, Keuangan dan Investasi), 1(4). 